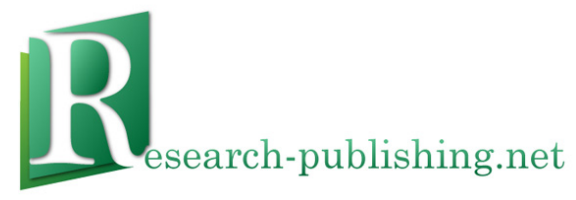

Published by Research-publishing.net

Dublin, Ireland; Voillans, France

info@research-publishing.net

(C) 2013 by Research-publishing.net

Research-publishing.net is a not-for-profit association

Case Studies of Openness in the Language Classroom

Edited by Ana Beaven, Anna Comas-Quinn and Barbara Sawhill

The moral right of the authors has been asserted

All articles in this book are licensed under a Creative Commons Attribution-Noncommercial-No Derivative Works 3.0 Unported License. You are free to share, copy, distribute and transmit the work under the following conditions:

- Attribution: You must attribute the work in the manner specified by the publisher.

- Noncommercial: You may not use this work for commercial purposes.

- No Derivative Works: You may not alter, transform, or build upon this work.

Research-publishing.net has no responsibility for the persistence or accuracy of URLs for external or third-party Internet websites referred to in this publication, and does not guarantee that any content on such websites is, or will remain, accurate or appropriate. Moreover, Research-publishing.net does not take any responsibility for the content of the pages written by the authors of this book. The authors have recognised that the work described was not published before (except in the form of an abstract or as part of a published lecture, or thesis), or that it is not under consideration for publication elsewhere. While the advice and information in this book are believed to be true and accurate on the date of its going to press, neither the authors, the editors, nor the publisher can accept any legal responsibility for any errors or omissions that may be made. The publisher makes no warranty, expressed or implied, with respect to the material contained herein.

Trademark notice: Product or corporate names may be trademarks or registered trademarks, and are used only for identification and explanation without intent to infringe.

Typeset by Research-publishing.net

Cover design: (C) Raphaël Savina (raphael@savina.net)

Fonts used are licensed under a SIL Open Font License

ISBN13: 978-1-908416-09-4 (Paperback, Print on Demand, Lulu.com)

ISBN13: 978-1-908416-10-0 (Ebook, PDF file, Open Access, Research-publishing.net)

ISBN13: 978-1-908416-11-7 (Ebook, Kindle Edition, Amazon Media EU S.à r.1.)

British Library Cataloguing-in-Publication Data.

A cataloguing record for this book is available from the British Library.

Bibliothèque Nationale de France - Dépôt légal: septembre 2013. 


\title{
7 FAVORing the Part-time Language Teacher: The Experience and Impact of Sharing Open Educational Resources through a Community-based Repository
}

\author{
Julie Watson ${ }^{1}$
}

\section{Abstract}

$\mathrm{T}$ he resourcefulness of part-time language teachers is often overlooked, despite the large numbers of such staff teaching in language departments across higher education. Part-time teachers typically juggle life work commitments and experience far fewer opportunities for professional development than their full-time colleagues. They frequently work in relative isolation, yet carry out their teaching duties enthusiastically and conscientiously, striving to provide as rich a learning experience as possible for their students, often spending a considerable amount of time in lesson and resource preparation. The aim of the JISC-funded FAVOR (Find a Voice through Open Resources) Project was to bring more part-time teachers into the open content movement, drawing on their wealth of resourcefulness and offering them something back for all their, often unrecognised, hard work. This case study will describe one participating institution's experience on the FAVOR Project, including an initial investigation into its impact on the postproject practices of part-time teachers. It will draw on a range of qualitative data gathered from individual and group meetings, teacher interviews, and reflective notes made by the institutional coordinator to present a picture of the experience from the part-time teachers' perspective.

Keywords: part-time teachers, OER learning design, adapting for sharing, LOC authoring tool, continuing teacher practice.

1. Principal Teaching Fellow in eLearning, Modern Languages, University of Southampton, UK; J.Watson@soton.ac.uk

How to cite this chapter: Watson, J. (2013). FAVORing the Part-time Language Teacher: The Experience and Impact of Sharing Open Educational Resources through a Community-based Repository. In A. Beaven, A. Comas-Quinn, \& B. Sawhill (Eds), Case Studies of Openness in the Language Classroom (pp. 85-95). (C) Research-publishing.net. 


\section{Context: Background to the FAVOR project}

The FAVOR Project (Find a Voice through Open Resources) was an OER (Open Educational Resource) initiative led by the Languages, Linguistics and Area Studies (LLAS) Centre at the University of Southampton and funded through JISC (Joint Information Systems Committee). Its primary aim was to engage part-time teachers of mainstream and lesser-taught languages in higher education and draw on their resourcefulness and experience to both generate and exploit Open Content (OC) for teaching and learning. Additionally, the project aimed to highlight the often unrecognised and undervalued resource that part-time teachers represent within our institutions. Nearly 30 parttime language teachers were coordinated from five UK Higher Education Institutions (Aston University; Newcastle University; School of Oriental and African Studies; University College London - School of Slavonic and East European studies; and the University of Southampton - Modern Languages) and by the end of the project, over 300 existing and created language teaching resources in 17 languages, produced in a range of digital media, had been shared through LanguageBox, an open content repository for language teachers and learners.

At the University of Southampton, five part-time teachers of four mainstream languages (French, German, Italian and ESL/EAP) were recruited and coordinated by the author. The teachers were involved in teaching language levels from beginner through to advanced, which included students on full-time accredited language modules run during the daytime and part-time evening language classes offered through the university's Lifelong Learning programme. The nature of their teaching ranged widely from language conversation classes to intensive EAP summer courses in all language skill areas (reading, writing, listening and speaking).

In the first phase of the project the part-time teachers drew on their existing banks of self-created language learning content for sharing as OER. In the second phase, the teachers designed and created new resources for use with their own classes, learning to use the LOC (Learning Object Creator) authoring tool. 
This case study focuses on the particular experiences of the Southampton group of part-time teachers in the project, and their perceptions three months after the project end. It offers a view, mediated by the coordinator (the author), which draws on her reflective notes and qualitative data gathered from individual and group meetings with the teachers. It also summarises some of the findings from data gathered during semi-structured interviews with the teachers after the conclusion of the project. These interviews particularly sought to determine how teachers' participation in the project might have impacted on their practice in the longer term.

\section{Intended outcomes: Drawing in and drawing out the part-time teacher}

There were several intended outcomes of the FAVOR Project.

By specifically engaging with part-time teachers, the project sought to draw in and recognise the value of these teachers in the context of the OC movement as well as realise some of the advantages of open practice among the group members. Such teachers often find themselves on the periphery of academic departments and separated both from each other as well as from colleagues in the mainstream teaching community. This situation arises for a variety of reasons, but, as one participant noted:

"Part-time language tutors do not spend lots of time in the university; for some, the only time (they spend) there is for teaching - some tutors do not even have a desk and a computer."

Working in relative isolation, these teachers have little opportunity for professional development even informally through exchange of ideas, mutual support and colleague interaction. Any innovative ideas or lessons that they may produce are noticed only by their students and their reward for these lies simply in the satisfaction of a lesson that was well received and achieved its teaching objectives. 
Teachers volunteered to participate and so were self-selected for the project. However, despite the intended outcome, several admitted to some initial scepticism about what they would be able to gain from involvement in the project or, at least, put into practice in the longer term:

"Before the project, I had nothing to do with e-learning and I had quite a few prejudices concerning e-learning. I always thought of it as red eyes and repetitive exercises... the system crashing down on me while I was trying to do it in class. That (apprehension) has all gone completely!"

In other circumstances, with their often busy agendas, juggling other commitments (e.g. young children; doctoral studies) and general lack of visibility even when on campus, this group of teachers are normally among the last to be reached in terms of new ideas or practices, especially if these might add to their workloads. Through involvement with FAVOR, these part-time teachers might become relatively 'early adopters' in the OC movement whereas without the project they might be difficult to reach.

The creation of a self-supporting community was also a hoped for outcome of the project, enabling teachers such as these to make and maintain contact with each other and develop a portfolio of OER together - learning from each other at the same time as developing confidence and awareness of what they could offer (and receive) through engagement in open practice.

\section{Nuts and bolts: Tools, training and support}

At the outset, the teachers created accounts in LanguageBox, the public repository used for storing and sharing the OER, and a personal profile page, which enabled them to establish their professional credentials and interests within the LanguageBox user community. They were supported through this process by the coordinator, an experienced LanguageBox user. For most, this action represented their first step in developing a professional presence online. By publishing some of their teaching and learning material as open content, 
these teachers could also 'find a voice' ("It's going out into the public with my name on it") and begin to build their own professional profiles, both through the online presence they created in LanguageBox (and in some cases through subsequent conference and workshop participation).

The teachers were then guided through identifying existing self-created language learning content to share as OER. They received technical training in adapting, if required, and uploading these resources to LanguageBox and adding the necessary metadata, including the use of a 'FAVOR' and 'UKOER' tag for all project outputs, to enhance the 'discoverability' of their resources by others. Interestingly, some of the teachers even began to experiment with new tools to extend the range of media for these OER:

"For example, the PowerPoint - I never used them before. I now have an idea how to do it. I'm using some more now for grammar - new ones that I made. It's opened a new path for me."

In the second phase, the teachers received training as a group in the use of the online LOC authoring tool to enable them to create OER from scratch. The LOC tool, designed and built through a collaborative endeavour at the University of Southampton, is being successfully used, particularly by language teachers, all over the UK and is a teacher-friendly authoring tool, with an explicit learning design for creating online resources in the form of interactive learning objects. It also comprises a pedagogic planning template, which supports teachers through the transition from designing learning activities for the face-to-face class to designing them for online use. This feature proved to be a particular attraction for the teachers (see Section 3). The coordinator provided regular feedback on teachers' draft plans for their 'Learning Objects', which enabled them to consolidate their LOC training and make progress with planning and creating new resources. She also trained teachers in uploading LOC tool outputs to LanguageBox.

Besides the sharing and creation of language-focused OER in a range of digital media, the project fostered a language teacher community of practice through 
the process of sharing and creating teaching resources, with LanguageBox acting as the focal share-point. This was evidenced when online groups began to spring up, creating networks of part-time teachers of the same language, at the same institution, or with a shared thematic or cultural interest (see Section 4).

\section{In practice: Learning with each other and from each other}

During the first phase of the project, in the course of initial group discussions about how and what to select to share from their existing banks of resources, teachers had decided that they wanted to adapt their OER in ways to make them more flexible for new users (e.g. by adding transcripts; tasks; suggestions for users). This was not a requirement; however, teachers modified many of their resources as they saw necessary, feeling the need to "...think carefully whether it needs to be improved" or made more suitable for reuse as OC. Only once these modifications had been made, were the resources felt to be ready for uploading to LanguageBox.

A University of Southampton FAVOR group was established within LanguageBox, allowing all of the teachers' uploads to be showcased in one place. Groups of teachers representing other universities in the project created similar groups. In addition to this, language- and topic-specific sub-groups also began to spring up (e.g. the Condividiamo (Italian) group; the Horn of Africa Project group; the Swahili Interest group) (see Figure 1). These 'resource aggregating' actions helped all teacher participants in the project, locally or nationally dispersed, to track and view recent project uploads and colleague activity through the shared focal point of LanguageBox, thus fostering the development of the wider FAVOR community.

For many participants, this phase had also represented an opportunity to develop greater technological awareness and enhance their technical skill base, through introduction to the concept of OER and shared repositories, and also by learning to repurpose their existing teaching content in a wider range of formats (see Figure 2). 
Figure 1. Three of the topic-specific groups in LanguageBox that grew out of the FAVOR project

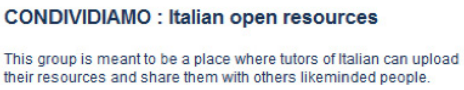

This group is meant to be a place where tutors of Italian can upload their resources and share them with others likeminded people.

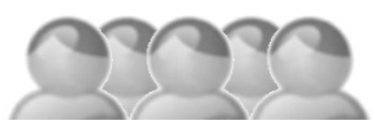

\section{The Horn of Africa Project (SOAS}

The group consists of teachers specialising in the Horn of African languages, headed by Jo Eastlake - the project leader. Image courtesy of www.public-domain-image.com.

\section{Swahili Interest Group}

We are crazy about Swahili - please join us with anything of interest. Let's share ideas.

Website: http:/hww learnswahili org.uk

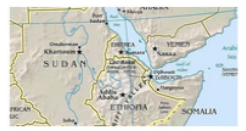

Figure 2. A participant's repurposed resource as a PowerPoint presentation for teaching basic description in French

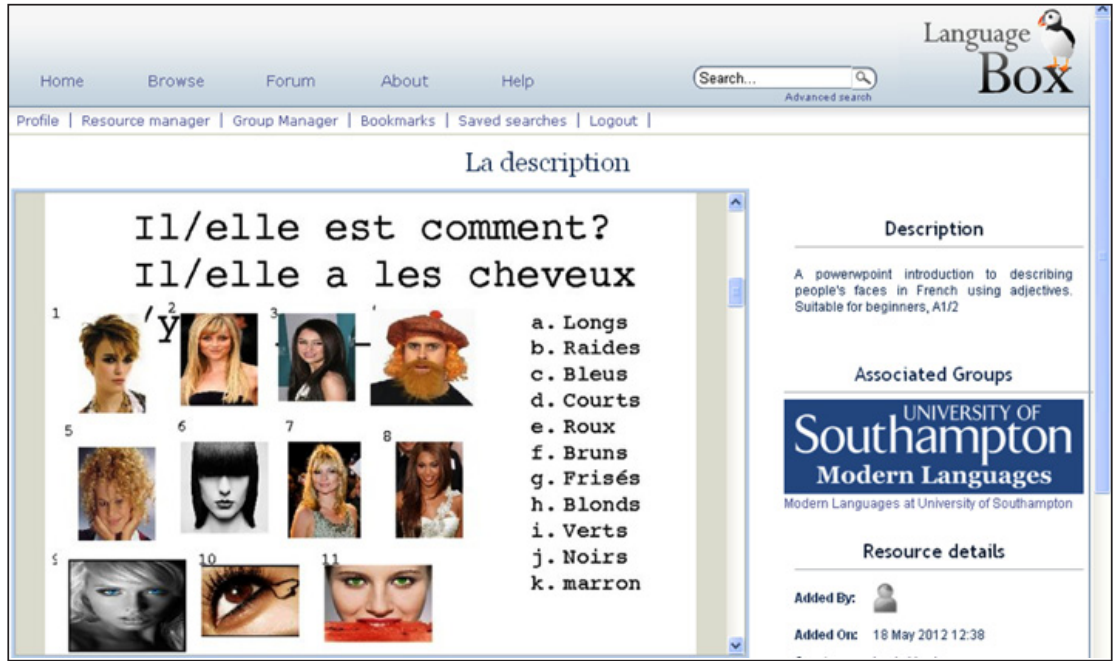

In the next phase, the teachers had received training in the use of the LOC authoring tool for creating new online teaching and learning resources. Postproject interviews with the part-time teachers highlighted exactly how useful 
the tool's embedded pedagogic support, especially the planning sheet, had been at this stage:

"What really helped is the [LOC planning] template..., [which] really impacted on the way I approach lessons. I'm not a language teacher by training; my degree is in translation, then Applied Linguistics. I had a lot of teaching experience but zero pedagogical training."

Learning to design and build online language learning resources with an authoring tool represented a step change for the teachers, as well as a challenge in terms of finding the time needed to commit to this phase. Nevertheless, all persevered and succeeded in producing thoughtfully-designed and activity-rich learning objects in their respective language teaching fields. The extent to which they had learned from each other as a community was also particularly noted by participants in the post-project interviews:

"I've looked at someone else's approach to teaching and then created my own resource from it."

"X had this idea how to deal with a text. It struck me as a really good idea. I'm thinking about it - is there a way to adapt it?"

"It's helped improve the quality of the resources I use... given me an opportunity to think about how I use resources and how others use resources."

In practice, the use of LanguageBox as a focal point for the project allowed parttime teachers to share not only their OER but also their ideas.

\section{Conclusion}

\subsection{Preliminary evaluation}

Besides the community-derived benefits, two major gains from the project were 
felt to be the teachers' engagement with new technological tools for delivering online language learning content (from simple PowerPoint to more complex Learning Object outputs), and the pedagogical gain from revisiting learning design through the LOC planning template and reflection about the reuse of the pedagogic approaches underpinning others' resources.

On one level, sharing teaching resources as OC only has meaning if others choose to reuse or repurpose them. This ultimate goal may not occur within the time confines of a project. However, as found in other OER initiatives, the benefits, and specifically, our understanding of the concepts of reuse and repurposing, do not have to be understood solely in terms of the actual online resources (e.g. Beaven, 2013).

The three-month post-project interviews shed some important insights into the question of resource reuse and repurposing. Three of the five teachers acknowledged having reused their own resources, while the other two reused those of others. Unsuitability of some of their created OER for the levels of the classes currently being taught was noted, and no repurposing had occurred due to lack of time at the start of the academic year. However, all participants mentioned the fact that they had 'reused' or adapted ideas or approaches that they had found underpinning the resources of others. Some also mentioned abstracting pedagogic principles and practices embedded in the LOC planning template:

"I have recycled ideas and targeted them towards my own students - no group is alike; I always find I need to retarget... I look for ideas more than for the actual resources."

"What I reused is this format because I really like that very much...I started being very aware of structure - at the beginning I had material sitting at home so I would just restructure it using the template, but then later I would go online looking for ideas... I take ideas from bits and pieces that are relevant to mine but change them."

This teacher went on to explain how she repurposed the teaching approach 
used in another teacher's German language picture story about the process of producing Christmas baubles, which required students to interpret and retell to each other in stages. She repurposed and extended the idea in the form of a German advent calendar requiring students to create a story around the pictures revealed each day. As she said, "the original gave me the idea".

The participants all cited their exposure to the design patterns implicit in the ideas of others as a particularly useful way in which the project had supported their teacher development. Pedagogic benefit was also noted to have impacted on classroom practice (i.e. reapplying LOC learning design principles when lesson planning).

\subsection{Concluding remarks}

Time will tell how far the teaching resources shared and created during FAVOR will be reused and repurposed by others; nevertheless, it was clearly stated to be the intention of the teachers themselves to do this when the right class arose and time permitted. The teachers' increased confidence in their own professionalism and development of a positive attitude towards sharing and benefiting from $\mathrm{OC}$ were highlighted.

Teacher gain in terms of increased sensitisation to the 'idea template' or 'learning design' inherent in their own OER and those of other people may ultimately be the most important outcome of this project. In this regard, FAVOR outcomes are in line with those of other OER initiatives (e.g. Borthwick, 2013; McGill, Beetham, Falconer, \& Littlejohn, 2010), proving that what we are discovering, as we move into the world of OC and practice, turns out to be a much richer experience than what we originally expected.

Acknowledgement. I would like to thank Bianca, Denise, Katy, Livia and Lucie, the part-time tutors at University of Southampton, for all their work in the FAVOR Project and for giving me permission to quote them. 


\section{Useful links}

FAVOR Project: https://www.llas.ac.uk//sites/default/files/nodes/6505/FAVOR-Final-report.pdf

LLAS: https://www.llas.ac.uk

JISC: http://www.jisc.ac.uk/

LanguageBox: http://languagebox.ac.uk/

LOC: http://loc.1las.ac.uk/

Condividiamo group: http://languagebox.ac.uk/group/26

Horn of Africa Project group: http://languagebox.ac.uk/group/17

Swahili Interest group: http://languagebox.ac.uk/group/20

\section{References}

Beaven, T. (2013). Use and Reuse of OER: professional conversations with language teachers. Journal of e-Learning and Knowledge Society, 9(1) 59-71. Retrieved from http://www. jelks.org/ojs/index.php/Je-LKS_EN/article/view/802

Borthwick, K. (2013). The FAVOR Project Final Report. Retrieved from http://www.llas. ac.uk/sites/default/files/nodes/6505/FAVOR-Final-report.pdf

McGill, L., Beetham, H., Falconer, I., \& Littlejohn, A. (2010). JISC/HE Academy OER Programme: Pilot Phase Synthesis and Evaluation Report. Retrieved from https:// oersynth.pbworks.com/w/page/29688444/Pilot\%20Phase\%20Synthesis\%20and\%20 Evaluation\%20Report 